\title{
Anthropology of development and the challenge of South-South cooperation
}

\author{
Letícia Maria Costa da Nóbrega Cesarino \\ University of California, Berkeley
}

\begin{abstract}
This article explores some of the challenges and potentials that the emerging phenomenon of South-South cooperation (SSC) might pose to major approaches in the international literature on the anthropology of development. Irrespective of particular politico-conceptual preferences, the latter's analytics have been largely crafted based on ethnographic work about development aid provided by Northern agencies or North-led multilateral organizations. Based on my own fieldwork experience with Brazil's contemporary provision of official technical cooperation in tropical agriculture to various countries in the African continent, I propose a discussion about four sets of themes: Foucauldian approaches to development based on notions of governmentality and discourse; the associated question of politics/depoliticization; the institutional aspect of development cooperation as a national and global industry and bureaucracy; and the question of ethnographic authority and the transit between what David Mosse has referred to as field (relations entertained with informants during fieldwork) and desk (relations entertained with academic peers during ethnographic writing).
\end{abstract}

Keywords: South-South cooperation, anthropology of development, Brazil, Africa

\section{Resumo}

Este artigo explora alguns dos desafios e potenciais que o fenômeno emergente da cooperação Sul-Sul coloca para algumas das abordagens prevalentes na literatura internacional sobre antropologia do desenvolvimento. Independente de preferências político-conceituais particulares, as perspectivas analíticas nesta última tem sido amplamente baseadas em trabalhos etnográficos sobre a ajuda para o desenvolvimento oferecida por organizações 
multilaterais ou agências bilaterais do norte global. Com base em experiência de campo com a cooperação técnica oficial em agricultura tropical oferecida pelo Brasil ao continente africano, proponho uma discussão acerca de quatro grandes problemáticas: abordagens foucaultianas para o desenvolvimento baseadas nas noções de governamentalidade e discurso; a questão da des/politização; o aspecto institucional do aparato da cooperação para o desenvolvimento enquanto uma burocracia e indústria global e nacional; $\mathrm{e}$ a questão da autoridade etnográfica e do trânsito entre o que David Mosse propôs chamar de campo (relações estabelecidas com informantes durante $o$ trabalho de campo) e mesa (relações estabelecidas com pares acadêmicos durante o processo de escrita etnográfica). 


\title{
Anthropology of development and the challenge of South-South cooperation
}

\author{
Letícia Maria Costa da Nóbrega Cesarino \\ University of California, Berkeley
}

\section{Introduction'}

Although a relatively new field in Brazilian anthropology, studies of international development and cooperation are not a novelty in the international literature. Both anthropologists of development and development anthropologists have, over the decades, accumulated a significant body of data, theories and methods for approaching these phenomena. ${ }^{2}$ As the many reviews available on the intersection between anthropology and development indicate (Hoben 1982; Escobar 1991; Ferguson 1997; Olivier de Sardan 2001; Green 2009), there can be sharp theoretical and political divergences between the various existing approaches - from highly critical, deconstructivist, more purely academic stances to applied efforts at improving the efficiency of development initiatives.

There is, however, one characteristic that is shared by most such literature: both empirical and theoretical studies have been overwhelmingly based on North-South experiences (and discourses) of international development. This should not come as a surprise, since most of these studies were produced by anthropologists from the so-called global North, or those who are based in Northern universities and research institutions. Moreover,

1 This reflection is part of my ongoing $\mathrm{PhD}$ dissertation research. For supporting the first four years of my studies at the University of California, Berkeley, I would like to thank Brazil's Ministry of Education (CAPES) and the Fulbright Foundation. For supporting my fieldwork in Brazil and West Africa, I thank CAPES, as well as UC Berkeley's African Studies Center and Institute of International Studies. I am very grateful to my supervisor Cori Hayden for being a dedicated interlocutor. I would also like to thank all of the colleagues and professors from whom I have learned in different stages of this project, especially Bruno Reinhardt. I also thank my field interlocutors, for the same reason.

2 Development anthropologists are commonly understood as those who do applied work for development agencies, while anthropologists of development are those for whom these agencies and their interventions themselves are an object of academic study. It is often the case, however, that the line between the two is blurred (Grillo 1997). 
development aid as we know it was a Western invention, and the United States and Europe have been, until recently, if not the sole, certainly the main actors in this process. Nevertheless, there have been salient changes with the increasing visibility and influence of so-called emerging donors, which include Brazil ${ }^{3}$ along with China, India, Russia, South Africa, Arab countries, and many others. Even though relations of cooperation among nations from the South are not new, during the last decade or so they have significantly increased in number, diversity, visibility, and impact, both on receiving countries and on the international development aid community at large.

Although Southern donors do converse with their Northern counterparts and might abide by some of the latter's proposals and standards, most of them make a clear point to remain free to make their own choices about how to provide cooperation (a term generally preferred over development or aid). There is, nonetheless, an important interplay between the two modalities of cooperation, be it in terms of articulation or competition. On the one hand, South-South cooperation (SSC) may be viewed as complementary to NorthSouth development aid, not only in terms of supplementary financial flows to compensate for declines in Official Development Assistance (ODA), but also in terms of the provision of technical expertise considered better suited to "Southern contexts." Triangulation, for instance, is becoming an increasingly common cooperation modality. ${ }^{4}$

Other kinds of relations between Southern and Northern donors may be marked by tension or competition. For instance, Northern actors have at times claimed that cooperation provided by the former is not sufficiently transparent, that it may be disrupting current attempts at harmonizing aid and making it more effective, and even spoiling the good work achieved by Northern aid thus far in domains such as good governance and fiscal responsibility in recipient countries. It could be that some Northern donors

3 Although here I will occasionally refer to Brazil as such, the country in fact rejects the label "donor." A reason for this refusal seems to be that, by principle, Brazilian cooperation does not involve direct money transfers. As such, it also remains independent from donor coordination arenas such as the Development Assistance Committee (DAC) of the Organization for Economic Development and Cooperation (OECD) (indeed, Brazil and the others are sometimes referred to as non-DAC donors; for a useful definitional exercise on South-South cooperation, cf. Leite 2012).

4 Triangular projects have a South-North-South architecture, whereby the Northern partner typically contributes with financial funds, and one of the Southern partners (i.e., Brazil) with expertise in some specific sector like tropical agriculture. 
also resent the leverage these new players may give to local actors in regions where the aid market is highly competitive, such as Sub-Saharan Africa. These and other remarks made by actors in the global North about emerging donors seem to be in fact directed mostly at China, which is in many ways exceptional amidst this already highly heterogeneous group.

The international anthropological literature has not kept pace with these and other changing realities. Even recent analyses like Maia Green's (2009) still define the "international development system" as a "network of actors, institutions and practices aligned around development objectives" associated with the OECD-DAC and the latest global yardstick for development, the United Nation's Millennium Development Goals (MDGs). Indeed, there are few comprehensive, ethnographically grounded studies on cooperation initiatives carried out by countries from the global South. ${ }^{5}$

A relevant question to ask is thus: what kinds of questions and challenges does the emerging phenomenon of South-South cooperation pose for mainstream anthropological approaches to international development? This paper will contribute by reviewing a few of the common themes and concepts that run through the international literature in the anthropology of development in light of insights derived from a particular South-South cooperation experience: contemporary technical cooperation in tropical agriculture between Brazil and Africa. As I will argue, some of the questions raised by the international literature can be quite readily asked of South-South initiatives; for others, anthropologists working at this new empirical frontier might prefer to look elsewhere for inspiration (e.g., Cesarino, in press).

\section{Governmentality and discourse}

A safe way to begin an appraisal of the more theoretically oriented anthropological literature on development is probably with Foucault, whose theories of discourse and governmentality have been quite popular, particularly among American and U.S.-based critical anthropologists. The best known early empirical work to put forth a Foucauldian approach to development in

5 Among the few exceptions are studies focusing on a recent hot topic in international development, China's growing presence in Africa (e.g., Alden et al. 2008; Langwick 2010). Kelly Silva's (2004) dissertation on cooperation for institution-building in East Timor remains a rare instance of ethnographic work approaching Brazil as a donor. 
anthropology was probably The Anti-Politics Machine (1994), James Ferguson's $\mathrm{PhD}$ ethnography about a rural development project in Lesotho (Southern Africa) funded by the Canadian International Development Agency and the World Bank during the 70's and 80's. His by now well-known argument suggests that, even though this project failed - not an uncommon outcome in the world of development - it produced effects (or "instrument-effects") which pertain to a broader systemic logic of "expanding bureaucratic state power" and "depoliticizing both poverty and the state" (:256).

Since then, other anthropologists have also sought inspiration in Foucauldian theoretical constructs for framing their ethnographic studies on development in Africa and elsewhere (e.g., Moore 1999, 2005; Li 2007). Others have chosen to focus less on the practice of development than on institutional discourse and policy (Sachs 1992; Escobar 1995; Crush 1997; Apthrope 1997; Anders 2005). The Dictionary of Development (Sachs 1992), assembled contributions from anthropologists and other critical scholars that further the deconstruction of development ideas such as planning, participation, and poverty. In one of the best known studies of this genre, the Colombian, U.S.-based anthropologist Arturo Escobar (1995) took inspiration in a chapter of The Anti-Politics Machine which craftily shows how World Bank discourse constructed Lesotho as an object amenable to development intervention, to sketch a broader critique of the role of the Bank and its development discourse in creating the Third World itself as an "other" to be developed by the West. Escobar's work is also an example of how anthropologists of development have drawn on insights from post-colonial theory, most notably Edward Said's Orientalism (Said 1979).

Besides discourse, the Foucauldian notion of governmentality has also enjoyed great popularity among U.S. anthropologists of development. More recently, it has appeared accompanied by other academic buzzwords to compose common references in the contemporary literature such as neoliberal or transnational governmentality (Ferguson \& Gupta 2002). These notions seek to encompass more recent developments such as the imposition of structural adjustment programs in Africa and elsewhere during the 80's and 9o's, and the emergence of new trends in international development since about the same time such as good governance, ownership, pro-poor policies, and selfreliance (Anders 2005; van Gastel \& Nuijten 2005). In contrast to the above mentioned works on discursive formations (not all of which enjoy substantial 
ethnographic embedding), the notion of governmentality seems more amenable to empirical research - for instance, by looking at how local groups are disciplined into becoming "proper' aid beneficiaries and clients" (Mosse 2005: 21), how policies, projects, evaluation reports and other expert documents are crafted (Mosse 2005; Mosse \& Lewis 2006), and how development experts construct messy realities as technical objects ( $\mathrm{Li}$ 2007).

It is not clear, however, whether a Foucauldian framework can encompass all of what goes on in South-South modes of cooperation. There is, at least in the case of Brazil, a difference in scale and scope between North-South development and South-South cooperation. The latter is generally more hands off than the former, for reasons that relate both to policy principles and to financial or managerial constraints. ${ }^{6}$ The vast majority of bilateral projects between Brazil and Africa, for instance, are carried out at a significantly smaller scale than those of the World Bank, Northern bilateral agencies, and other established international development institutions. In agriculture, with possible future exceptions, ${ }^{7}$ projects never really reach the scope and scale of, say, integrated rural development. The immediate "client" of Brazilian cooperation is therefore not the peasant farmer, "undifferentiated and ungendered ... established as the object in need of exogenous agricultural science and 'expertise"' (Crush 1997: 16; also Escobar 1995). Rather, projects most often take the form of a direct, more or less horizontal relationship between agricultural research institutions from both sides; transfer of technology to farmers is considered a task to be performed largely by the African counterparts. Therefore, the working notion of the "local peasant" comes less from an external bureaucratic expert apparatus than from local actors who provide their account of those who are to be the ultimate beneficiaries of cooperation. In some cases, the image that surfaces is not that of an indigenous peasantry paralyzed by centuries-old backward modes of cultivation and in need of salvation by

6 This might be specific to Brazil and probably most other emerging donors. In terms of financial means, China is again an exception; in terms of general principles, it has joined the others in charting common tenets for South-South cooperation, which are found for instance in a 2009 Declaration by the G-77 and China (UNCTAD 2010: 8).

7 Brazil's provision of technical cooperation in agriculture to African countries is currently undergoing some rearrangements. The trend backed by the Brazilian Cooperation Agency has been of phasing out small scale, short-term projects in order to focus efforts and resources on so-called structuring projects. These involve more time, more money, larger scales, and may be carried out by means of triangulation with Northern donors - as is the case of the upcoming Pró-Savana in Mozambique, probably Brazil's largest official agricultural project in the African continent thus far. 
scientific expertise, but that of people who have already been touched by modernization (that is, by previous development projects) - and who have not been saved by it. This is thus less about the dichotomy commonly found in the literature between foreign/modern neocolonialists and an indigenous/traditional peasantry (Escobar 1995) than about relations between postcolonial subjects that have been differently shaped by successive historical layers of unequal integration into the margins of the capitalist world system.

By the same token, Brazil does not deploy human and material resources at a scale capable of engendering or intensifying practices related to governmentality or bureaucratization in recipient countries. Recent efforts to extend its reach in Africa notwithstanding, Brazilian cooperation has not (or has not yet) established a capillary presence in the global development apparatus which, "in the countries of the South and especially in Africa, is omnipresent and 'unavoidable"' (Olivier de Sardan 2001: 731). It is possible, however, to inquire about elements of governmentality in Brazilian cooperation bureaucracies and executing institutions, as well as in their concrete interactions with African counterparts or with other donors, particularly in projects that are triangulated with Northern parties.

On the other hand, a look at the recent history of Brazil and of its African partners indicates that what has been referred to by the literature as neoliberal governmentality has in fact taken on multiple forms in different times and places. Clearly, there are significant differences between the forms and effects of the Washington Consensus reform agenda in Latin America and in Africa (e.g., Mkandawire \& Soludo 1999; Sader 2008). Like "development" before it (Cooper \& Packard 1997; Moore 200o), "neoliberalism" has been appropriated by developing countries in ways that are significantly refracted by their local and regional histories and politics. Care should be taken not to gloss over these differences by focusing only on the ways neoliberalism has been framed and imposed by Northern and multilateral aid bureaucracies and experts on the global South. Significantly, more recent ethnographic works such as those by Moore (2005) or Li (2007) have resorted to other analytical tools to "complement" Foucault - most notably, Gramsci's hegemony - to paint a more comprehensive and faithful picture of the heterogeneous ways in which governmentality has actually played out in particular Third World contexts.

It is not difficult to appreciate the productivity of the notion of 
governmentality for critical approaches to historical forms situated, so to speak, at the top of the modernization ladder - where one needs to look behind the veil of the rule-of-law, democracy, modern science, and so forth in order to envisage the play of power relations. But in most postcolonial nation-states of the global South, power relations have always been very much in the foreground; state sovereignty has never been a fully successful "fiction" - a fiction that many Northern scholars now claim to be unmasking (Anders 2005: 40). History as well as political economy - or more precisely, historically built economic inequalities in the world system - are at the very core of South-South cooperation discourse, if not practice; ${ }^{8}$ here, issues involving sovereignty are indeed vital. ${ }^{9} \mathrm{~A}$ key part of its geopolitical background is in fact an ongoing struggle to reform the Bretton Woods Institutions established in the late 1940s. In the case of Brazil, this is perhaps most explicitly manifested in the country's longstanding quest for a permanent seat on the U.N. Security Council. After all, to become a provider of cooperation speaks as much to one's Southern peers as to Northern powers; far from being an exclusively horizontal relationship across the global South, South-South cooperation is also about gaining recognition from the North.

This is not the whole story, though. South-South cooperation encapsulates a sort of double-bind with respect to North-South development: while emerging donors (especially those historically situated within the Western sphere of influence such as Brazil) seek recognition as equal players from developed countries, their self-image and practices are also constructed in opposition to them. Some versions of Brazil's discourse ${ }^{10}$ claim that part of what its cooperation is (or should be) derives from its own decades-long

8 Whether and how history and political economy are incorporated in the practice of projects is something that only detailed ethnographic inquiry could ascertain. What is certain though is that some of them - like the Cotton-4 Project Brazil is conducting in West Africa, which emerged in the aftermath of a dispute with the U.S. over cotton subsidies at the WTO - owe their very existence to struggles over global imbalances.

9 Tania Li (2007), and before her Donald Moore (2005), has suggested that even in North-South development the other two elements of Foucault's triad - sovereignty and discipline - play a part as important as governmentality.

10 It is important to emphasize that although there are broad identifiable trends in Brazil's official SSC discourse, it is not homogeneous even at a formal level. The oppositional elements for instance tend to be watered down when discourse is uttered within North-led multilateral fora such as the OECD, the World Bank and even the U.N., which have spared no efforts to attract Brazil's and other SSC efforts to their own regulatory orbit - or, as others would have it, to "hijack" them (Sá e Silva 2009:50). 
experience as a receiver of development aid from the North. This experience would, today, partly translate into how not to provide it - for instance, by not tying conditionalities to aid. The stress on sovereignty also plays a key role here: one of the guiding principles of South-South cooperation is to respect the sovereignty of cooperating partners by not interfering in each other's domestic affairs. From this oppositional perspective, aid provided by the global North is regarded as a way to impose on developing countries its own views on free trade, good governance, macro-economic management, and the like - in other words, much of what anthropologists and other critical scholars have been calling neoliberal governmentality.

Following these broader principles, South-South projects are deliberately meant to differ from the "standardized package solutions to problems" (Grillo 1997: 20) allegedly delivered by Northern agencies: they are supposed to be demand-driven; conditionality-free; based on experiences that have proven successful domestically, which are then tailored to the beneficiary country's particular problems and socio-natural environments; and negotiated from the start with the recipients of cooperation, who will also play a central role in implementation. Of course, as with North-South development, South-South principles might not always hold in practice. Moreover, there seems to be important differences between the various emerging donors as to the extent and way in which such shared principles are applied. Again, only a significant body of comparative ethnography will allow ascertaining such differences.

From what was said, it can also be surmised that relations of cooperation between countries from the global South put the question of Orientalism (Said 2003) in development discourse in quite a different perspective than the one generally found in the literature. After all, the "other" of emerging donors is not limited to recipient countries; it includes in a central way Northern donors (and possibly also other Southern donors) in relation to whom they define their principles and policies. But in general, South-South cooperation discourses do not go to the same length as their Northern counterparts in describing (or constructing) the "other" to be developed (or cooperated with). Where this happens, it might well be true that that "other" is as imagined as the one in North-South development - but surely not in the same way, and not with the same consequences.

Thus in Brazil (and probably elsewhere), Africa has been largely looked at through a mirror-image provided by its own postcolonial experience, 
not only in terms of Brazil's historically peripheral position within the Western hegemonic world system, but of how this positionality articulates with the country's own processes of internal colonialism. I propose to call this way of articulating power and knowledge in peripheral settings nation-building Orientalism, to contrast it with Said's original notion based on the empire-building experiences of Britain, France and the U.S.. In the case of Brazil-Africa relations, this has involved a series of oscillating and at times contradictory interactions between international relations across the Southern Atlantic and a variety of domestic processes involving race relations, economic development, global trade, cooperation and agricultural policies, and so forth.

A salient example is Gilberto Freyre's notorious depiction of African slaves as a key ingredient in Brazil's harmonious melting pot, which has been a subtle (and sometimes open) reference during engagements between African partners and Brazilian cooperation administrators and frontliners significantly, much less the latter than the former. In official discourse, past connections between the two sides of the Southern Atlantic brought about by the European slave trade are put forth both as a moral justification for (i.e., a retribution to Africans for their contributions to Brazilian civilization) and a facilitator of cooperation (due to historically produced similarities in culture, besides those "accidental" ones in geography, climate, and so forth). Besides this topography of natural-cultural similarities, assumptions about a shared temporality are also at play in the widespread claim that Brazil has much to contribute to (especially Sub-Saharan) African countries, since it would have already experienced (and overcome) many of the development problems they face today.11 But this assumption is played out less in terms of a general teleological-hierarchical timeline (Ferguson 2006) than in relation to particular - and quite contemporary - issues pertaining for instance to agricultural research, policy, and trade. The examples could be multiplied.

Thus, in other words, not even in discourse does South-South cooperation aim to be as all-encompassing as North-South development. This presents a different kind of problem to the anthropological literature and the observation that development tends to fail, and that recurrent failure would

11 This is another assumption that looks very "Brazilian" at first, but is in fact widely shared by other emerging donors - including the shared culture claim, commonly present for instance in the case of India. 
even have a certain functionality in its self-reproduction. One could perhaps say that since the goals of most South-South initiatives are, from the start, more focused and less ambitious, they are therefore more likely to succeed. But even if we recognize, as do Ferguson and others, that development is not really about success or failure but about the concrete effects it produces, it is likely that detailed empirical research on South-South cooperation will unveil effects other than governmentality or bureaucratization.

\section{Politics and Depoliticization}

A close corollary to the notions of governmentality and discourse is that of the depoliticization of relations; here, development appears as a technical issue that dispenses with both history and politics (Ferguson 1994; Mitchell 2002; Li 2007). But the claim that in the practice and discourse of development politics is generally swept under the rug is hardly limited to Foucauldian approaches, or even to the academic literature. Developers themselves sometimes recognize the "institutional and political constraints on development, the close interactions, the importance of a political economy rather than just economics, of bureaucracy and the way it operates" (Kaufmann 1997: 123). However - and here divergent currents in the literature would agree - such issues are rarely incorporated in the problem-solving (or problem-constructing) protocols of development institutions.

It might not take much to demonstrate the depoliticization of local and regional relations in development discourse - in some cases, a straightforward comparison between World Bank reports and academic works on the same topic, as Ferguson (1994) did for Lesotho, will do the trick. Indeed, such divergences can be quite flagrant, something which makes it hard not to agree with Ferguson's claim that development texts constitute a quite different genre than scholarly ones, with their own configuration of relations between power and knowledge.

Beyond textual analyses, Ferguson and others have sought to describe how depoliticization takes place in the practice of development projects (cf. some of the chapters included in Crush 1997, Grillo 1997, or Mosse \& Lewis 2006; also Li 2007). Indeed, most ethnographic accounts have focused on the receiving end of development - not surprisingly, since fieldwork among aid recipients is more akin to the discipline's traditional practice of observing localized 
communities that are, in general, more easily accessible to (because more socially vulnerable than) the ethnographer. Many anthropologists have in fact arrived at development while conducting more conventional types of ethnographies; after all, development is a fact of everyday life for villagers in many parts of the world, Africa in particular (Grillo 1997; Olivier de Sardan 2001).

Thus, ethnographies have shown how local or regional power relations are excluded from the construction of the "development problem" by being strategically ignored or deemed irrelevant for the technical solutions proposed by the experts (Ferguson 1994; Li 2007). This attitude towards local relations might lead developers to grossly misinterpret indigenous practices and politics, or to promote local brokers who might not reflect power relations as they prevailed prior to the development intervention (Ferguson 1994; Mosse 2005). In the literature, an intrinsic connection is generally implied between such a refusal to bring local and regional political relations into project design and execution, and an exclusion, at the level of expert discourse, of "political-economic questions - questions about control over the means of production, and the structures of law and force that support systemic inequalities" (Li 2007: 11). ${ }^{12}$

But politics (and its concealment) plays into development practice and policies across the board, and not only among those to be developed. "Gameplaying" - as one of Georgia Kaufmann's informants put it - occurs "from the political agendas of [donor] countries to the grassroots politicking of the local big men" (1997: 128). ${ }^{13}$ Developers themselves are well aware that politics wield high influence upon how development is conceived and put to work

12 As Grillo (1997) and others have noted, since the 1970's the development apparatus itself has moved beyond policies based on an economic orthodoxy exclusively focused on overall growth towards new emphases such as poverty reduction and participation, as well as new client categories like women and small farmers (Gardner and Lewis 1996: 20-2). Thus the "new architecture of aid" (Mosse \& Lewis 2005) has come up with protocols for incorporating local issues, such as participatory approaches. Many anthropologists have argued, however, that these may end up domesticating local politics by controlling agenda-setting, and by representing "community issues as technical" and local politics as "insignificant to [the projects'] future trajectories" (Green 2009: 408; Grillo 1997; Li 2007; cf. Goldman 2005 for a similar assessment with regards to environmentalism in the World Bank).

13 In this respect, Kaufmann makes a rare reference, even if en passant, to "another layer of politiking and hidden agendas" besides the North-South polarity - the South-South and North-North ones (1997: 129). Indeed, lateral relations between donors seem to play a major role in the overall configuration of international development, but they are even less amenable to direct ethnographic observation than individual donor institutions - how could one make for instance an ethnography of the DAC-OECD, and its backstage interactions? 
at the donor level. As another of Kaufmann's interlocutors revealingly put it, besides all their technical expertise, in order to do their job developers need "a power map" (1997: 128). But how can ethnographers go about charting such power maps on the developers' side?

The limited accessibility to the daily routine of developers (especially when they leave project grounds for their air-conditioned organizational enclaves in recipient or donor countries) and the use of methods other than ethnography (like interviews or documental analysis) to study them are not just a question of method. One could ask whether the constraints involved in doing participant observation among developers might not lead more easily to sweeping theoretical statements like the ones put forth by critical anthropologists like Escobar and Ferguson. Contrastively, studies that succeed in focusing ethnographically on the provider side tend to be more careful when generalizing. Unfortunately, such studies are much less common, and for obvious reasons. Practices internal to international cooperation agencies, financial institutions, global governance bodies and the like are much more difficult to access by direct modes of observation than those of local villagers or development frontliners. Moreover, as will be discussed below, even when access is eventually granted by formal or informal means, there can be further difficulties involved in putting in writing some of the issues found in the field.

It is often the case that anthropologists gain access to development institutions by working for them as expert consultants, as part of a secondary career to the academic one (Moore 2001; Goldman 2005; Li 2007; Green 2009), or in order to "pa[y] their way [into the policy world] with knowledge products" (Mosse \& Lewis 2006: 3). In this case, they turn, even if momentarily and ambivalently, from development anthropologists to anthropologists of development. British anthropologist David Mosse (2005) has reflected extensively on his decade-long experience as a participant-insider in a long term rural development project in tribal western India funded by the British Department for International Development (DFID). His analytical emphasis was on the political effort expended by development agents of all functions and ranks to close the gap between policy and practice that inevitably arises during the execution of projects. Mosse sees development, then, much as Latour sees science: as the always-provisional outcome of a process of "purification" of messy realities; hence, the stability of particular development policies and discourses would only last as long as the network that supports it. 
It is significant that Mosse draws on Latour instead of Foucault in order to talk about questions of politics and depoliticization in development (Mosse 2005, 2006). Different from Ferguson, Li and others - who seem to be mostly concerned with an academic reading public and are thus better able to sustain a separation between "field" and "desk" (Mosse 2006) - Mosse was personally immersed in the very network he took as his object of study. When he wrote his ethnography, he had in mind both his informants in development and his colleagues in academia; the politics of writing ethnography in this kind of situation can be quite tricky. One can wonder for instance whether the reasons why Foucault is popular among many anthropologists who keep their intellectual reflections separate from any applied work in development - or why their academic colleagues who are embedded professionally and personally in the world of development might prefer someone like Latour instead - go beyond fashionable choices in the academic marketplace. After all, theory is not free-floating; it is also embedded in the anthropologist's web of academic and non-academic social relationships (Green 2009; Venkatesan \& Yarrow 2012). It is, in Strathern's terms, a knowledge practice like any other. In this sense, actor-centered frameworks that propose to approach politics across the spectrum of development activities (Olivier de Sardan 2001; Mosse \& Lewis 2006) could also include the anthropologist and her colleagues in these networks. This issue will be resumed below with respect to the question of ethnographic authority in the anthropology of development.

Although depoliticization at all abovementioned levels is likely to be present in South-South engagements, as already alluded to in the previous section, this kind of cooperation is always and already politicized in a way North-South development is not. Perhaps most fundamentally, the very historical constitution of nation-states in the global South does not allow them the "god trick" - the subject position of viewing everything from nowhere (Haraway 1988) - so frequently denounced by critical anthropologists with respect to Northern development institutions such as the World Bank. Since at least the non-aligned countries' 1955 Bandung Conference (and its outgrowth, the G-77), developing countries have been making quite clear the - to stick to the Harawayan lexicon - situatedness of their stances towards international development, trade, and the like. The influence of neo-Marxist approaches such as dependency theory has contributed in fundamental ways to this "politicization of development in the South at both grassroots and state levels" 
(Gardner \& Lewis 1996: 18; also Ferguson 1997). In regions like India and Latin America, this politicization did not take long to lead to situated academic critiques of the "development establishment" (Cooper \& Packard 1997: 14).

On the other hand, and as already discussed above with respect to governmentality, at least in the case of Brazilian cooperation, politics at the local or even regional level does not seem to be something project staff has to commonly deal with; even if by default, it is something to be managed by the African counterparts. Local politics may certainly interfere even with projects that are restricted to a technical relation between research institutes, as is the case with much of technical cooperation in agriculture - for instance, in the choice of where experimental stations will be located, or who will be attending trainings. But how this is dealt with within the ambit of projects, and to which effects, is still an unanswered ethnographic question. Overall, then, one could perhaps say that if, at the most macro level of world systemic relations, politics is very much at the foreground of South-South cooperation, it gradually fades away as cooperation approaches the most micro level of local relations - not necessarily because local politics is rendered technical, but simply because it tends to fall outside of the immediate relational scope of project activities.

Another issue raised by the literature is how "rendering technical" (Li 2007) creates an ontologic-epistemological hierarchy between project participants. Li has argued that the "practice of rendering technical confirms expertise and constitutes the boundary between those who are positioned as trustees, with the capacity to diagnose deficiencies in others, and those who are subject to expert direction" (7). In spite of the rhetoric of horizontal exchange and mutual learning prevalent in South-South cooperation, it is quite likely that, in practice, projects do inscribe some sort of asymmetry between the partners. But it is also very probable that it is constructed differently than in North-South engagements.

As with other emerging donors, Brazil's cooperation discourse does not assume a gap - after all, to do so would undermine the very possibility of successful cooperation. But it does this in an ambivalent fashion: at the same time that there is talk of horizontality, exchanging knowledge and sharing experiences, cooperation discourse draws on the assumption that African countries have much to learn from Brazil's store of successful experiences 
in sectors such as tropical agriculture. ${ }^{14}$ If there is no ontological gap, then, there is at least an asymmetry which, even though not at the forefront of discourse, becomes quite evident in practice - for instance, when there are visible disparities between Brazilian and African research institutions in terms of availability of (untied) financial resources, physical infrastructure, appropriate equipment and materials, or disciplined technical staff. But in this respect, a difference vis-à-vis orthodox development discourse is that, in South-South cooperation, such asymmetries are generally regarded as a product of history, of an unprivileged position in the world system which Southern donors have also occupied in the past, and which they see themselves as having partly overcome.

A last point to be noted here is that even though South-South cooperation draws heavily on the denunciation of inequalities at the level of the world system, it has very little to say about inequalities at the domestic level of both provider and recipient countries. Indeed, this is a sequitur to some of the above mentioned principles of South-South cooperation, such as noninterference in the partners' internal affairs and respect for their sovereignty. But internally to emerging donors questions may be raised about cooperation's relations with domestic challenges. After all, some say, countries like Brazil, China, India or South Africa have their own lot of poor people to take care of, and their own national development problems to tackle. These kinds of questions are likely to become increasingly louder, and so are the particular responses that governments are likely to be already crafting.

In the same vein, one could inquiry about struggles internal to emerging donors over their South-South cooperation policies. Northern development has had its own internal disputes - between alternative models (e.g., the "economic growth model" versus "the user-friendly social-development alternative" during the 1990's; Kauffman 1997: 128), over how and where to deploy aid budgets, and so forth. Emerging donors surely have similar issues to grapple with. Thus, questions to be approached by anthropologists working

14 This is a key assumption that interestingly echoes Truman's call for putting the United States' "store of technical knowledge" to the service of developing nations (Cooper \& Packard 1997). And just as, at the time of Truman's mythic 1949 announcement (which arguably first named international development as such), he was "keen to distance his project form old-style imperialism" (Gardner \& Lewis 1996: 6), today Brazil and other emerging donors also strive to differentiate South-South cooperation from "traditional" development aid. 
on South-South cooperation could include: What are the (general or sectorspecific) competing views on SSC at play within each emerging donor, and in each of the institutions involved in project design, management and execution? To which domestic political struggles do they speak? To what extent do competing views on how to provide South-South cooperation relate to shifts in North-South development policies?

\section{The development bureaucracy and industry}

A quite common remark in the literature already mentioned here is that, in the practice of development, project failure is more the rule than the exception. If international development has consistently shown such a high rate of project failure, how has it been able to survive, and even expand, over the decades? Ferguson's somewhat functionalist response is that it serves other, systemic ends such as entrenching bureaucratic state power (Ferguson 1994). A more mundane way of responding is by noting that development aid agencies are "actual institutions, which ... spend billions of dollars a year" (Gardner \& Lewis 1996: 2), and that those who make their (sometimes life-long, sometimes occasional) careers in them would only have to lose if the poor countries to whom they provide aid would actually develop. This is but rhetorical reasoning, of course, since any historical account will show that development is about much more than the institutions and organizations that claim this label. ${ }^{15}$ But the sheer size and reach of the so-called development (or aid) industry and bureaucracy has led many anthropologists and other scholars to stress the institutional and organizational inertia underlying it.

Many of the stakes of this industry are indeed quite concrete, and can be grasped quantitatively through the significant share of aid funds that end up returning to donor countries. This is more explicit in the case of tied aid, whereby funds come back in the form of goods and services purchased from

15 These include "departments and bureaucracies in colonial and post-colonial states throughout the world, Western aid agencies, multilateral organizations, the sprawling global network of NGOs, experts and private consultants, private sector organizations such as banks and companies that marshal the rhetoric of development, and the plethora of development studies programs in institutes of learning worldwide" (Crush 1997: 6). The historical roots of development are many, and the abundant literature on this topic has approached them from various angles - from ideology to political economy, from institutions to subjectivities, from imperial centers to colonial and post-colonial peripheries (e.g., Sachs 1992; Escobar 1995; Cowen \& Shenton 1995; Cooper \& Packard 1997; Gardner \& Lewis 1997; Rist 2002). 
enterprises based in the donor country. But more generally, aid funds support the operation of huge bureaucracies as well as high pays for expatriate experts and consultants. In this sense, development is a business like any other, and, as any other organization, the ones involved in it have a degree of in-built institutional inertia. Individuals who have made their careers in the development bureaucracies and industry might embody such systemic inertia at the micro level by reproducing organizational culture and values.

The self-reproducing nature of the institutional apparatus of development might also be sustained by a common, and some would even say "inevitable" (Olivier de Sardan 2001: 741), fact observed by much of the ethnographic literature: the disjunction between policy prescriptions and the practical implementation of projects and programs. Such disjunction would stem not only from local "resistance" to development interventions - as focused on by much of the kind of anthropology Olivier de Sardan calls populist - but also from incoherences intrinsic to development institutions themselves. Thus, David Mosse and others have focused on how "the practices of development actors are not governed by policy prescription, but are generated by very different and diverse administrative, political or social-relational logics which are concealed by rationalizing policy" (Mosse 2005: 22; Mosse \& Lewis 2005). Development workers thus perform a continuous work of mediation between the two often contradictory levels of policy and practice - something that would contribute to "recycling" unsuccessful experiences back into policy and thus keep the machine going: what Li has referred to as "a parasitic relationship with its own shortcomings and failures" (2007: 1). ${ }^{16}$

If the development industry were limited to providers of aid, the stakes would already be high enough. But recipients of aid, too, are not only part of it, but can contribute in fundamental ways to its systemic inertia. After all, developing countries' elites and government officials are also in the business of development. A clear symptom of this are the endless debates among developers and think-tanks about whether aid helps or harms African countries by feeding a vicious cycle of dependency. Attempts by leading donors to implement an Aid Effectiveness Agenda during the past decade or so have

16 Olivier de Sardan (2001: 734) remarked the important difference to be observed between the public discourse of managers and decision-makers, and the private discourse of field staff who actually execute the projects. The latter are not as naïve about policy-practice disjunctures as many critical anthropologists might assume, especially those who did not carry out fieldwork among developers (also Eyben 2010). 
further demonstrated the resilience of this institutional inertia. As a former Dutch cooperation minister has recounted in an interview with Africawatch, her efforts at trying to make aid more effective by apparently unproblematic measures such as replacing expatriate doctors with their local African counterparts (who were otherwise being brain-drained to developed countries) have been met with strong resistance from both vested interests on the Dutch side, and African leaders unwilling to "bite the hand that feeds them" (Herfkens 2010). Local actors may also play a part in the representational work to manage the gap between policy and practice (Moore 2001).

Moreover, the Southern branch of the industry is not limited to governments and elites. As Mosse and Lewis (2006) and Bierschenk and colleagues (2000) have pointed out, development is deeply imbricated in networks of brokers (or, in the French lexicon, courtiers) at the local (or transnational, in the case for instance of the African diaspora) level who also make a living out of development and derive local prestige from engaging with projects. These actors struggle by the formal or informal means available to attract and channel the bountiful resources of international aid according to their own designs and strategies. Speaking of them in a way that perhaps few of his U.S. colleagues would dare, French anthropologist Olivier de Sardan has remarked that, as much as their Northern counterparts who are so sanguinely attacked by what he calls populist and deconstructivist anthropologists, local cadres too are "experts in double language; the maneuvering, intrigues, struggle for influence, attempts at monopolization, rhetoric discourse, and manipulations come from all sides" (2001: 736).

In Brazil, the institutionalization and professionalization of South-South cooperation into specialized bureaucracies well-equipped with their own knowledge-producing expert apparatus is at a relatively early stage - one could perhaps say, it is still in its "heroic phase". Therefore, it might be too early to sketch out the differences between how the industry works there and elsewhere. But ongoing cooperation projects indicate some possible differences, which may or may not persist in time. A potentially significant particularity of technical cooperation provided by Brazil is that staff in charge of project execution is almost entirely recruited from the ranks of the dozens of national and subnational state institutions that, according to the first report of the kind released by the Brazilian Cooperation Agency (IPEA and ABC 2010), execute official cooperation. These include research institutes (for 
instance, in health and agriculture), federal and state universities, professional schools, federal ministries, and the like. In Brazilian cooperation, then, most frontliners do not have a career in the development industry, and do not depend on SSC projects for a living. In some cases, such international experience may count for advancing their careers in their home institutions; but the opposite may also be the case, for instance, when research scientists momentarily put aside their routine research work to participate in cooperation projects from which they will not necessarily derive any personal career benefit. Indeed, motivations for participating in cooperation are multiple, but seem mostly unconnected with securing employment or income, as is more often the case in specialized bureaucracies and organizations involved in managing and implementing Northern aid (Kaufmann 1997; Herfkens 2010).

Moreover, if it is true that, in practice, development projects and programs follow less "high modern" grand planning designs than "are pulled together from an existing repertoire, a matter of habit, accretion, and bricolage" (Li 2007: 6), such a repertoire may be highly heterogeneous. When designing and implementing projects, Brazilian developers work together with a host of other institutions and organizations - Southern counterparts in bilateral projects, Northern agencies in triangular ones, or multilateral organizations such as UNDP. Moreover, project frameworks are inspired not only by international development standard procedures and expert protocols; perhaps more fundamentally, they draw on the executing institutions' experiences both as receivers of cooperation and as agents of national development. It is possible that, in contrast with Northern aid where "the bureaucracy of government seems to treat development as an extension of economics and financial planning" (Kaufmann 1997: 117), Brazil's relatively decentralized model for providing cooperation is more closely attached both to general foreign policy guidelines on the one hand, and to sector-specific national priorities and ways of designing and executing projects (e.g., in agriculture, public health, education, and so forth) on the other.

In Brazilian cooperation, the figure of the broker (Mosse \& Lewis 2006; Bierschenk et al. 2000) is also likely to be at play, even if less so at the village level. Among the multiple competencies required of brokers - "organizational, linguistic, presentational, and relational" (Mosse 2006: 16) - the linguistic aspect is fundamental in the recent thrust for expanding Brazilian cooperation beyond non-Portuguese speaking countries in Africa. After all, it 
is not so common to find nationals from Francophone or Anglophone Africa who can also understand and speak good Portuguese, and not all Brazilians on project staff fluently speak a foreign language (although many do). Other kinds of brokerage also exist that follow broader patterns in the field of international development, for instance, individuals who were trained abroad, who transit between national institutions and multilateral organizations such as the United Nations and the World Bank or, in the case of agriculture, transnational research networks such as the Consultative Group of International Agricultural Research (CGIAR).

Finally, another visible trend to note in the global development industry is the growing importance of non-state actors like NGOs and private companies. Such actors are important not only because they account for a good share of an increasingly diverse pool of international developers, but because their growing presence raises important questions concerning sovereignty and accountability (Ferguson 2006; Mosse 2005: 7). Much of South-South cooperation, however, has been provided by state institutions and actors, and in Brazil this prevalence is nearly absolute. Perhaps the chief private sector organization providing official technical cooperation to African countries, the National Service for Industrial Training (SENAI), receives support from the Brazilian Cooperation Agency for its activities overseas. Special credit lines for exports of (agricultural and other) equipment to Africa have been provided by the state-run National Bank for Social and Economic Development (BNDES). Brazilian companies have been also investing in Africa, in sectors such as energy, construction, and agribusiness (Patriota 2011), and upcoming projects might involve the Brazilian private sector in a more significant way. Finally, some Brazilian religious groups have been also increasing their presence overseas.

\section{On ethnographic authority}

David Mosse (2006) has perceptively approached the issue of ethnographic authority in the anthropology of development in terms of a characteristic of knowledge production in the discipline since at least Malinowski: the separation between field and desk. This is the sense in which Mosse claims that anthropology is "anti-social" - the work involved in constructing an analytical object amenable to appreciation by academic peers during the process 
of writing (the desk) involves partly or totally severing the social relations established with one's informants during the research process (the field). For many reasons, anthropologists studying development might not be able to perform such a trick - at least, not with impunity.

As mentioned above, many of the difficulties faced by the anthropologist wishing to study development and cooperation lay at the beginning of the research process, in negotiations with development institutions to secure access to field sites. But at the other end of the research spectrum, she may also confront numerous problems when writing about sensitive issues observed during fieldwork, or making statements that could displease or even harm some of the interlocutors or institutions studied. Mosse himself faced significant hurdles when writing his ethnography of developers; former informants and co-workers went as far as his university and professional association to press for changes in the manuscript "on the grounds that the book was unfair, biased, contained statements that were defamatory and would seriously damage the professional reputation of individuals and institutions, and would harm work among poor tribals in India” (Mosse 2006: 935-6). A solution to this dilemma found by Kaufmann (1997) was simply to let her informants read and re-write passages in which they were quoted prior to publication.

These and other potential ethical hurdles might be a reason why ethnographies focusing on developers are generally more arid than others; they might not bring much of the Malinowskian "imponderabilia of actual life", the mundane details and storytelling rhythm characteristic of ethnographies involving people who can be more easily rendered anonymous (and harmless). When writing about development projects, it is difficult, if not impossible, to maintain the subjects' anonymity if teams have a limited number of members, as is often the case. And yet, as Kaufmann has noted, anonymity is vital; many informants working in the development industry are very well "aware that they have much to lose, that their words could be dangerous for them" (1997: 111).

In many ways, development might be an even more sensitive field than other kinds of "study up" ethnographies (Nader 1969). Here, the public image of agencies and institutions is one of their most vital assets, and visibility in the international arena is itself one of cooperation's main objectives. After all, much of development is about creating a positive image of donor countries vis-à-vis receiving countries, other donors, and their own domestic 
public opinion. As Olivier de Sardan (2001) has put it, development institutions are fundamentally "input-oriented" (734): donor governments everywhere have to continuously muster support from domestic constituencies for the deployment of part of their budget in foreign aid. In Brazil, the visibility of South-South cooperation initiatives is still dim, not only in the public sphere but even within the state itself. As a senior official from the Brazilian Cooperation Agency once told me, pointing to the National Congress' modernist building standing just across from the windows of the Agency's headquarters in Brasilia, "we are not yet under their radar. But when we are, we must be ready to show the impacts we have had on recipient countries." Public image may also be a sensitive matter for some executing institutions. Therefore, once a bond of trust is achieved, it becomes both productive and constraining for the anthropologist - productive in the field, but quite likely constraining at the desk.

Many of the anthropologists of development who have set out to discuss these and other issues of ethnographic authority and ethics in research felt compelled to do so because of their dual positions as academic analysts and expert consultants (Mosse 2006; Green 2009) - while others are content to resolve the issue by affirming an inherent incompatibility between the "ethnographic appreciation of ... complexities" and "the position of expert" (Li 2007: 3). But even when there are no formal attachments, anthropologists doing fieldwork in cooperation and development institutions may end up building commitments to their interlocutors, which might (just as in conventional types of ethnographic fieldwork) involve giving them something back, whether immediately or not. Sometimes anthropologists end up becoming voluntary workers or performing small ad hoc tasks like translation. I was at times put in the project evaluation box, and even though I was always quick to disappoint my interlocutors by informing them that my dissertation was in no way applied research, the expectation sometimes remained that I would be able to provide some kind of feedback that might eventually prove useful to their work.

These informal exchanges notwithstanding, like their colleagues from Northern institutions, Brazilian anthropologists could participate more directly in the field of international cooperation. Olivier de Sardan (2001) agrees with Mosse that process monitoring and feedback procedures are "no doubt the best practical contribution anthropology can lend to development 
actions" (731). In the same vein, Grillo (1997) highlighted project appraisal and assessment as well as policy advice as arenas where anthropologists could play a role. Thus far, Brazilian cooperation has not invested much of its scarce resources in evaluation, but it seems that it is beginning to do so. And even though, as remarked above, Brazilian projects typically do not reach the village level - one for which anthropologists are especially well-equipped due to their singular disciplinary skills -, the discipline's vocation for mediating between different cultural worlds could play a role in cooperation, as well as its integrative view on domains that development thinking tends to compartimentalize: the political and the technical, the local and the global, the contemporary and the historical, and so forth. Finally, Olivier de Sardan also remarked that, given the above mentioned disjunction between policy and practice so common in development, anthropologists can also play a role of "rappel au réel": as permanent reminders of where and how development discourse strays from practice (and the other way round) (2001: 733).

Among the potential obstacles to the involvement of Brazilian anthropologists and other academic professionals in cooperation (as workers or researchers) are questions of cosmopolitanism and language. A pattern noted by Kaufmann in her "partial ethnography" of British developers is how many of them are led to the industry by the experience of having been directly exposed to "other cultures" (1997: 114) early on in life, at home or abroad. This kind of experience is less common in the developing world (and probably more so in Latin America) than in Europe and the U.S. - which, as key nodes in the modern world system, have long attracted immigrants from around the world as well as carried out their own policies of sending their young abroad for forays into the world peripheries as students or volunteers.

Moreover, Brazilian anthropology has not invested as much as its "empire-building" counterparts in the global North in the production of its own ethnographically embedded corpus of knowledge on regions in the global South where Brazilian cooperation is, or wishes to be, present. ${ }^{17}$ Knowledge about Africa or Asia (albeit less so about Latin America) has been mostly gained second-hand from research done in the global North. Even though

17 Some Brazilian anthropologists have argued for the nation-building character of the country's social sciences, as opposed to the empire-building drive of their Northern counterparts (e.g., Cardoso de Oliveira 1999; Stocking 1982). 
there have been decisive steps in this direction ${ }^{18}$ Brazilian anthropologists have a long way to go to produce not only original data but also their own (situated) theories about international cooperation and development.

This would also entail more investment in language training. Many anthropology programs in the U.S. for instance make the learning of a foreign language a requirement, and there are scholarships and grants specifically provided for this purpose. In Brazil, on the other hand, students more often than not have to invest in language training on their own. I ended up having to perform fieldwork in two languages besides my native Portuguese (English and French), in which luckily I already had some previous training. Time and resource constraints in Brazilian academia would not have allowed me to take my research project forward had I needed to be trained from scratch in a new fieldwork language - let alone do multi-sited research, another frequent "burden" of development ethnography (Watts 2001: 295).

These practical constraints have important consequences for academic knowledge in anthropology, especially if we accept Green's invitation to take the discipline's own knowledge practices as an object of attention - particularly in terms of what happens at the desk, that is, those "practices of dialogue, criticism and pedagogy" (Green 2009: 398) which constitute what can be considered as authorized knowledge in the discipline. As discussed above, the study of development and cooperation institutions can make untenable the separation between field and desk. Regardless of whether one's informants were also one's co-workers or not, the public of academic works on development is hardly limited to academia. Unlike anthropology's original subjects (although even they have been rapidly changing), development workers everywhere have "the means to read, criticize and contest the piece of work produced [by the anthropologist], to raise questions on equal or even superior footing" (Souza Lima apud Valente 2010). One could say (with Kauffman 1997) that, when "watching developers," the issue of ethnographic authority is turned into "an exchange of information as equals" (:110), or might even be reversed.

Kauffman's solution, as noted above, was to let her informants share the writing process. That resulted in many of the original statements being "rectified" or re-written in the idiom of jargon; or, as Kauffman herself admitted,

18 For instance, the contributions to Vibrant's dossier on "South South anthropology" (Silva 2008). 
some things - important things - had to be left "off the record" (:125). Experiments in writing in which the anthropologist makes room for her field interlocutors are not really new in the discipline - but these have typically involved types of informants more familiar to anthropologists such as, in the case of Brazil, indigenous peoples (e.g., Albert \& Kopenawa 2010). But what about giving voice, in the ethnography, to informants like the developers, who already have the means by which to express their own voice? Would that also be co-authorship, or just plain censorship? Wouldn't it contribute to loosening anthropology's critical grip? Or would it allow, to the contrary, for the emergence of new kinds of knowledge practices and partnerships for action? No doubt, these and other questions are bound to be answered by practice. ${ }^{19}$ It could be that anthropologists writing about South-South cooperation from the South will come up with different commitments and stances towards them.

Over a decade ago, Grillo (1997) called attention to differences between national anthropological traditions and their respective approaches to development. His appraisal referred, however, only to the U.S. and European traditions. He did note the remarkable absence of "developing country anthropologists" (:4) in international academic debates on development - but restricted his corrective to the anthropological production from South Asia, India in particular (a language bias here?). With the recent surge in South-South cooperation efforts, it is time for anthropologists from Brazil and elsewhere to also pitch in with their empirical and theoretical contributions to the field, lest the international literature will remain the picture of a landscape that has already changed.

\section{References}

ALBERT, Bruce \& KOPENAWA, David. 2010. La chute du ciel. Paroles d'un chaman yanomami. Paris: Plon.

ALDEN, Chris; LARGE, Daniel \& OLIVEIRA, Ricardo Soares de (Eds). 2008. China returns to Africa, New York: Columbia University Press.

APTHROPE, Raymond. 1997. "Writing development policy and policy analysis plain or clear. On language, genre and power". In: Chris Shore and Susan

19 Cf. also the recent volume edited by Venkatesan \& Yarrow (2012). 
Wright (eds.), Anthropology of policy. Critical perspectives on governance and power. London and New York: Routledge. 34-45.

BIERSCHENK, Thomas; CHAUVENEAU, J. P. \& DE SARDAN, Olivier (eds.). 2000. Courtiers en développement: les villages africaines en quête des projets. Paris: Karthala.

CARDOSO DE OLIVEIRA, Roberto. 1999. "Peripheral anthropologies 'versus' central anthropologies" Journal of Latin American Anthropology, 4(2): 10-30.

CESARINO, Leticia. In press. "Brazilian post-coloniality and South-South cooperation: a view from anthropology" Portuguese Cultural Studies.

COWEN, Michael; SHENTON, Robert. 1995. “The invention of development”. In: Johathan Crush (org.), Power of development. New York and London: Routledge. 25-42.

CRUSH, Jonathan. 1997. Power of development. New York and London: Routledge.

D’ÁVILA, Jerry. 2010. Hotel Tropico. Brazil and the challenge of African decolonization. Durham: Duke University Press.

ESCOBAR, Arturo. 1991. "Anthropology and the development encounter: the making and marketing of development anthropology" American Ethnologist, 18(4): 658-82.

ESCOBAR, Arturo. 1995. Encountering development. The making and unmaking of the Third World. Princeton, NJ: Princeton University Press.

EYBEN, Rosalind. 2010. "Hiding relations: the irony of 'effective aid"'. The European Journal of Development Research, 22(3): 382-97.

FERGUSON, James. 1994. The anti-politics machine. "Development", depoliticization, and bureaucratic power in Lesotho. Minneapolis and London: University of Minnesota Press.

FERGUSON, James. 1997. “Anthropology and its evil twin. 'Development' in the constitution of a discipline”. In: Fredrick Cooper \& Randall Packard (orgs.), International Development and the Social Sciences. Berkeley: University of California Press. pp. 150-75.

FERGUSON, James. 2006. Global shadows. Africa in the neoliberal global order. Durham and London: Duke University Press.

GOLDMAN, Michael. 2005. Imperial nature. The World Bank and struggles for social justice in the age of globalization, New Haven (CT): Yale University Press.

GREEN, Maia. 2009. "Doing development and writing culture: exploring 
knowledge practices in international development and anthropology" Anthropological Theory, 9: 395-417.

GRILLO, Ralph; STIRRAT, R. (eds.) 1997. Discourses of development.

Anthropological perspectives. Oxford and New York: Berg.

HARAWAY, Donna. 1988. "Situated knowledges: the science question in feminism and the privilege of partial perspective". Feminist Studies, 14(3): 575-99.

HERFKENS, Eveline. 2010. "Africans should speak up and defend their own interests". Africawatch, November 2010: 52-6.

HOBEN, Allan. 1982. "Anthropology and development". Annual Review of Anthropology, 11: 349-375.

IPEA and ABC. 2010. Cooperação brasileira para o desenvolvimento internacional, 2005-2009. Brasília: IPEA/ABC.

KAUFMANN, Georgia. 1997. "Watching the developers: a partial ethnography”. In: Ralph Grillo \& R. Stirrat (eds.), Discourses of development. Anthropological perspectives. Oxford and New York: Berg. 107-32.

LANDAU, Georges. 2008. "O Brasil e a cooperação internacional para o desenvolvimento”. Revista de Economia e Relações Internacionais, 6(12): 10316.

LANGWICK, Stacey. 2010. "From non-aligned medicines to market-based herbals: China's relationship to the shifting politics of traditional medicine in Tanzania”. Medical Anthropology, 29(1): 15-43.

LEITE, Iara C. 2012. "Cooperação Sul-Sul: história, conceito e marcos interpretativos". Observador On-line, 7(3): 1-40.

LEWIS, David; MOSSE, David. 2006. Development brokers and translators. Ethnography of aid and agencies. Bloomfield, CT: Kumarian Press.

LI, Tania Murray. 2007. The will to improve. Governmentality, development and the practice of politics. Durham and London: Duke University Press.

MITCHELL, Timothy. 2002. The rule of experts. Egypt, techno-politics, modernity. Berkeley: University of California Press.

MKANDAWIRE, Thandika; SOLUDO, Charles. 1999. Our continent, our future.

African perspectives on structural adjustment. Trenton, $\mathrm{NJ}$ and Asmara, Eritrea: Africa World Press.

MOORE, Donald. 1999. "The crucible of cultural politics. Reworking 'development' in Zimbabwe's Eastern Highlands”. American Ethnologist, $26(3): 654-89$. 
MOORE, Donald. 2005. Suffering for territory. Race, place and power in Zimbabwe. Durham: Duke University Press.

MOORE, Sally Falk. 2001. "The international production of authoritative knowledge: the drought-stricken West Africa”. Ethnography, 2(2):161-89.

MOSSE, David. 2005. Cultivating development. An ethnography of aid policy and practice, London and Ann Arbor (MI): Pluto Press.

MOSSE, David. 2006. "Anti-social anthropology? Objectivity, objection, and the ethnography of public policy and professional communities”. Journal of the Royal Anthropological Institute, 12: 935-56.

MOSSE, David. \& LEWIS, David. 2005. The aid effect. Giving and governing in international development. London and Ann Arbor (MI): Pluto Press.

NADER, Laura. 1969. "Up the anthropologist: perspectives gained from 'studying up'”. In: Dell Hymes (Ed.), Reinventing anthropology. New York: Random House. pp. 284-311.

OLIVIER DE SARDAN, J. P. 2001. "Les trois approches en anthropologie du développement”. Revue Tiers Monde, XLII(168): 729-54.

PATRIOTA, Thomas. 2011. Le Brésil, un partenaire de l'Afrique qui s'affirme. Paris: IFRI.

RIST, Gilbert. 2002. The history of development. From Western origins to global Faith, New York: Zed Books.

SÁ E SILVA, Michelle. 2009. "South-South Cooperation: past and present conceptualization and practice”. In: Lisa Chisholm \& Gita Steiner-Khamsi (eds.), South-South Cooperation in education and development. New York: Teachers College Press. 39-61.

SACHS, Wolfgang (ed). 1992. The development dictionary. A guide to knowledge as power. London and New Jersey: Zed Books.

SAID, Edward. 1979. Orientalism. New York: Vintage.

SILVA, Kelly. 2004. Paradoxos da auto-determinação. A construção do EstadoNação e práticas da ONU em Timor-Leste. PhD Dissertation, Social Anthropology, University of Brasília, Brasil.

SILVA, Kelly. 2004. (ed.). 2008. "Dossier 'South-South Anthropology”. Vibrant, 5(2).

STOCKING, George. 1982. "Afterword: a view from the center". Ethnos, 47(I-II): 172-86.

UNCTAD. 2010. South-South Cooperation: Africa and the new forms of development partnership. Economic development in Africa 2010 Report. New 
York and Geneva: United Nations.

VALENTE, Renata. 2010. A GTZ no Brasil. Uma etnografia da cooperação internacional para o desenvolvimento. Rio de Janeiro: E-Papers.

VAN GASTEL, Jilles; NUIJTEN, Monique. "The genealogy of the 'Good Governance' and 'Ownership' Agenda at the Dutch Ministry of Development Cooperation”. In: David Mosse \& David Lewis (orgs.), The aid effect. Giving and governing in international development. London and Ann Arbor (MI): Pluto Press. pp. 85-105.

VENKATESAN, Soumhya \& YARROW, Thomas. 2012. Differentiating development. Beyond and anthropological critique, New York and Oxford: Berghahn Books.

WATTS, Michael. 2001. "Development ethnographies” Ethnography, 2(2): 283300.

\section{About the author}

The author holds an M.A. in Social Anthropology from the University of Brasília (Brazil), and since 2007 is a PhD student in the Social Cultural Anthropology program at the University of California, Berkeley. Her chief areas of interest are science and technology studies, anthropology of development, postcolonial studies, and anthropology of anthropology. She has published on public debates on biosafety, stem cell legislation, and more recently, South-South relations, with a focus on Brazil-Africa.

Received October 2, 2011, approved April 4, 2012 